\title{
Communicating Compassionately in a Crisis: John Curtin and Journalists, 1941-1945@
}

\author{
Caryn Coatney, PhD.
}

\author{
Journalism Lecturer \\ University of Southern Queensland \\ Education City, 37 Sinnathamby Boulevard \\ Springfield Central, Queensland 4300 \\ Australia
}

\begin{abstract}
Professional communicators face more demands to develop caring and trustworthy relations with journalists. Corporate leaders increasingly need to develop skills in communicating compassionately with news teams during a largescale crisis or public emergency. Recently, scholars have been advocating for a historical approach in using the lessons of previous successes in crisis communication. One of the most acute emergencies in history has been the Second World War. Although often overlooked, the war generated remarkable innovation in political leaders' engagement with the media. Relatively little scholarly attention has been paid to Australian wartime prime minister John Curtin's exceptionally close relations with journalists from the US, Canada and Australia. His journalismoriented ethos was forgotten as post-war leaders developed the technique of delivering impersonal, unidirectional news conferences to the largely undifferentiated mass media. Scholarly interest has recently resurged into communicators' compassionate performances as they deliver personalized messages to audiences. This paper uses rarely researched archives that finds among the wartime leaders, Curtin elevated journalists' roles to convey public appearances of being a caring prime minister, good neighbour and citizens' friend. This conception of ethos is useful for the study of communicators' roles in portraying compassion, trust, and friendship towards journalists during an extended crisis.
\end{abstract}

Keywords: Crisis communication, Franklin Delano Roosevelt, journalism, John Curtin, leadership communication, media relations, World War II.

\section{Introduction}

Crises are often testing grounds that make or break long-lasting professional relations between managers and journalists(Waters, Tindall \& Morton, 2010). The relationship is especially significant for professional communicators because the potential for misinformation is immense as journalists continuously report on the outbreak of an emergency(Young, 1999).Often, textbooks advise that professional communicators need to be credible, compassionate and committed towards journalists and disclose information openly to foster a shared culture between the two groups. Therefore, expressions of compassion have become the typical fare of crisis communication as leaders try to persuade journalists to relay reassuring messages to citizens during escalating crises(Auer, 2020). For their part, journalists frequently report that they have mixed reactions to interacting with professional communicators because of their need to be detached, distant observers when reporting on a crisis(Rios, Hinnant \& Park, 2009). There is also a risk that leaders may use times of crisis and urgency to promote their individual authority over journalists and overlook the valuable communication lessons learned from previous events (Faessel, Falk \& Curtin, 2020).As Young (1999, p. 9) writes: "On a long view managements do not learn from history as much as they might. They live, don't learn and let die. The whole system has to be overhauled and hindsight turned into foresight." The lessons of history are often difficult to learn because these are not simple formulas.

This study focuses on one of the most critical events in crisis communication, the Second World War. This was an era when major forces converged, including the rise of democratic leaders who were well-versed in public speaking, the growth of communication technology and engaged, media-savvy citizens. The era was often forgotten in post-war communication studies that mostly viewed impersonal, one-way forms of communication to the largely undifferentiated mass media (Craig, 2016). More recently, researchers have shown the value of more personalized, emotive and compassionate forms of communication during a crisis (DuBrin, 2020; Fisher, Iles \& Herovic, 2020). This study re-evaluates the crisis communication techniques of wartime to glean insights for professional communicators.

Behind the scenes, major leaders were deeply immersed in ways to befriend journalists during World War II. US President Franklin Delano Roosevelt, British Prime Minister Winston Churchill and Canadian Prime Minister Mackenzie King (1893-1950) carefully practiced radio scripts to cultivate a relatively new style of intimate, personalized talks to listeners (Baldoni, 2003; Bradenburg \& Braden, 1958; King, 1893-1950). 
They relied on journalists to portray their compassionate leaderships and elicit citizens' endorsements. In a letter to Churchill(cited 1950, p. 200), Roosevelt commented on "that delightful god, which we worship in common, called 'the freedom of the press"'. Both Roosevelt and Churchill recruited journalists to be their media advisors and they developed extensive public relations units. In Canada, Mackenzie King (1939) unsuccessfully sought government backing to hire a journalist, and wrote in his diary: "What I need above everything else is a first-class modern journalist, full of vitality and colour, who would make my life and work known to the public" (p. 454). He complained:

Men in the [public] Service think that once anything is on Hansard [the official report of parliamentary debates] that it serves the purpose, whereas Hansard is of really no value in reaching the public. The only thing of value is the press reports(p. 454).

Leaders began developing interactive news conferences to signify compassionate governance.

Yet it appears that no other wartime leader spent as much energy to cultivate journalists as Curtin.This study conducts a rare analysis of Curtin's news interviews, secret briefings and confidential memorandum about his relations with journalists from Australia, Canada and the United States. He shared war secrets with journalists in twice-daily news interviews during most of his prime ministership (Coatney, 2016). He gave more frequent briefings than those of the other Allied leaders(King, 1893-1950; Perloff, 1998; Tait, 2008). His intimate interviews were frequently obscured during the post-war style of leaders' large, impersonal media conferences (Craig, 2016). The role of personalized, political messaging has re-emerged during recent research into the mediatisation of politics, with leaders relying on the media to convey emotion(Davis, 2019; Fisher, Iles \& Herovic, 2020). This article sets out to recover Curtin's journalism-oriented ethos to influence the news portrayal of his intimate, compassionate prime ministership.

This study is informed by the conception of ethos in assessing Curtin's relations with journalists. According to Aristotle's concept of ethos, a speaker performs rhetorical acts to appear as 'the good man' to citizens by signifying the traits of arete (virtue), phronesis (practical wisdom) and eunoia (a caring attitude). Aristotle advanced the term, ethos, for recommending a speaker's development of a personal character, or persona, to evince credibility among listeners. "Persuasion is achieved by the speaker's personal character when the speech is so spoken as to make us think him credible ... character may almost be called the most effective means of persuasion he possesses"(cited 2010, p. 7).Curtin emphasized the educative purpose of the classical performer's rhetorical display: "The one has a message to deliver. If the message is disliked, it has a mission to make it loved"(1917).

This study is also based on the concepts of the public sphere and democratic governance developed by Habermas and Castells. The Habermasian ideal of the public sphere envisaged cooperative dialogue among equals as journalists dispassionately reported political views to citizens (Habermas, 1989, 2006). More recently, journalism studies have taken an emotional turn (Jorgensen, 2020). Increasingly, scholars have investigated the role of emotions in the public sphere, situating journalism as a form of emotional labor that relays compassionate messages to news audiences (Dworznik-Hoak, 2020; Thomson, 2018). According to Castells (2007, 2008), communication and information are fundamental sources of power in the public sphere. Politics can be staged for the media to create symbolic messages of trust about a leader so as to obtain citizens' support. The concepts of ethos and the public sphere are useful for exploring the meaning of power in journalists' representations of compassion and leadership.

First, this article's literature review reveals gaps in the research of Curtin's relations with Allied journalists as a historical model for crisis communication. Secondly, this study outlines its methodological approach to ascertain his ability to persuade journalists to report favourably on his compassionate leadership. Thirdly, the findings are made that he expanded the nation's public sphere to involve more in portraying his role as a friend and neighbour to citizens.

\section{Literature Review}

Contemporary researchers have theorized that the notion of ethos extends to an audience's perceptions of a speaker's credibility. Communication researchers have drawn upon the Aristotelian traits of arete, phronesis and eunoia for ascertaining a speaker's ethos (Dix, 2015; Marsh, 2006). A speaker's persona needs to manifest these components to be persuasive: "There are three things which inspire confidence in the orator's own character - the three, namely, that induce us to believe a thing apart from any proof of it: good sense, good moral character, and goodwill"(Aristotle, cited 2010 , p. 60). Aristotle implied a fourth component of ethos: the speaker's prior reputation (Carroll, 2004; Smith, 2004). A speaker should persuade another person to give an account of the orator's credibility to the audience. "With regard to moral character: there are assertions which, if made about yourself, may execute dislike, appear tedious, or expose you to risk of contradiction ... 
Put such remarks, therefore, into the mouth of some third person"(Aristotle, cited 2015, p. 18). This paper shows Curtin's ability to persuade journalists to act in the role of "some third person" by promoting them as his "continuous trusted personal contact" for portraying his prime ministership (Alexander, 1971; Aristotle, cited 2015, p. 18.

Aristotle's interactive concept of ethos was gradually obscured during the development of political rhetoric for an expanding public sphere. Modelled in Aristotelian fashion, Cicero's $D e$ Oratore explored the conception of ethos to generate a political speaker's "enthusiasm and something like the passion of love"(Cicero, cited 2016, p. 95). An innate rhetorical genius, or ingenium, was the least mentioned requisite for oratorical performance (López, 2013). Cicero's follower, Quintilian, recognised a speaker's need to cultivate audience perceptions as appearing as 'the perfect orator, who cannot exist unless a good man' (Quintilian, 1891). Furthermore, Quintilian recommended artful improvisation through continual practice to cultivate appearances of speaking extemporaneously (Holcomb, 2001). For Habermas $(1989,2006)$, these types of rhetorical interactions took place in a realm of freedom based on rational discussions. Medieval scholars published few rhetorical treatises by the eleventh century (Murphy, 1974). Rhetoricians extended the conception of ethos to forms of print journalism by the Renaissance (Raymond, 2005). At this time, it was recognised that in order to create a truly "public" opinion, the mass media needed to be a "linkage" between two domains, between personal and official opinions. Scholars of modern democracies adopted Grimaldi's definition of rhetoric as involving all human discourse including political communication (Moss, 1997). A narrow, unidirectional conception of ethos became prevalent with the rise of twentieth-century fascism (Peters, 1996). Leaders increasingly favoured larger interviews that designated unequal roles to journalists and restricted their access to information. By the 1990s, more scholars treated the mass media, in Craig's terms, as an "iconic Other" (Craig, 2016). Contemporary researchers have adopted a broader conception of ethos based on reciprocity between the speaker and audiences (Carroll, 2004).

There is limited scholarship on leaders' compassionate communication during a crisis. As Liu, Iles \& Herovic (2020) have remarked, most research in this area has focused on managing organisations' images. Likewise, there is little research into journalists' reporting of compassionate messages. This paucity can perhaps be attributed to journalists' allegiance to the ideal of objectivity. Modern journalists have often subscribed to the role of being a distant and detached observer(Wahl-Jorgensen, 2020). Even so, more scholars have viewed leadership as a communicative act that involves journalists to encourage audiences to care about a crisis or disaster (Banwart, 2020: Nicotera, 2020). DuBrin (2013, p. xi) defines a crisis leader as "a person who leads group members through a sudden and largely unanticipated, negative, and emotionally draining circumstance."Leaders often try to involve journalists in shaping disasters and crises as moments of heightened drama, where the purpose of eliciting emotions in this way is to "bring the story closer" and educate the reader (Wahl-Jorgensen, 2020). The traditional newspapers remain relevant for leaders to demonstrate trust and transparency (Davis, 2019). As Raupp (2019) remarks: "traditional news media, in particular leading newspapers, can be considered an arena in which elite actors take a stand on matters of general interest." The traditional media remainas effective tools for leaders communicating about a crisis because these can be easily and quickly shared to widespread audiences(Hannides, 2015).More researchers are advocating the lessons of history to develop successful relations between professional communicators and journalists(Fife, 2018; Ratzan, Sommariva \& Rauh, 2020).

Scholars have analysed the wartime era as a time of tireless political efforts to court the press. Churchill, Roosevelt and Mackenzie King had been journalists and they demonstrated exceptional skill in cultivating various sections of the press. Even so, theirnews briefings often remained formalized and structured (Hallahan, 2003; Jackson, 2007; Perloff, 1998).Although several scholars have delved into Curtin's press interactions, this study has found that he expanded the ways that a prime minister promotes a compassionate ethos to newspaper reporters (Day, 2006; Lloyd, 1988; Lloyd \& Hall, 1997). Before becoming the Australian Labor Party (ALP) Prime Minister on October 7, 1941, Curtin was the editor of labor-oriented newspapers, The Westralian Worker and The Timber Worker, for about 13 years. Also, he was a state district president of the journalists' union, the Australian Journalism Association. To promote positive press interactions, Curtin hired the first full-time prime ministerial press secretary, Don Rodgers

(Rodgers, 1971). Perhaps he was influenced by Franklin Delano Roosevelt's decision to employ the first presidential press secretary, Stephen T. Early, in 1933. While journalists agreed to withhold confidential military news, they were not subject to political censorship (Coatney, 2016). No previous researcher has focused on Curtin's deliberate tactics to develop a compassionate journalism ethos to win press support during his exceptionally informal interviews. This study answers the research questions: 
- Which strategies of compassionate communication did Curtin develop to elicit journalists'support?

- Which factors influenced journalists in portraying his compassionate ethos?

\section{Methodology}

This study has conducted a multi-method approach to discover Curtin's techniques that persuaded journalists to visualize and define his compassionate ethos to Australian audiences. First, the impact of his media statements in his interviews will be ascertained by determining the extent to which journalists favourably reported his messages. A study has been made of the keywords in 11 of his major speeches, particularly his emphases of inclusive language, such as "we", "us", "our" and "the people"; ideals about "freedom", "liberty", "democracy" and "independence"; as well as his emphases of threats (Curtin, 1941a, 1941b, 1942a, 1942b, 1942c, 1942d, 1943a, 1943b, 1943c, 1944a, 1944b). This analysis aims to show the extent to which journalists selected, amplified and reproduced his language for readers. For this purpose, this article considers how journalists portrayed his news messages in the next day's issues of four Australian dailies - The Age, The Canberra Times, The Sydney Morning Herald and The West Australian (1941-1945). To contextualise the findings, the sample also includes American newspapers including The New York Times, Time magazine and The Washington Post as well as Australian newspapers, Army News, The Courier-Mail, The Daily Telegraph, The Herald, The Mercury and the Sunday Times. This analysis is based on the Pew Research Center's Project for Excellence in Journalism formula that a news article is deemed "positive" if two-thirds of the statements appear to support a leader (Public Broadcasting Service, 2009). These analyses glean an understanding of Curtin's persuasive abilities to influence the coverage of his media interviews.

Secondly, other historical news archives reveal how Curtin structured his media conferences to appear as two-way discussions with reporters (Alexander, 1971; Cox, 1973; Reid, 1972-1973). This study will investigate the day-today media routines that provided opportunities for Curtin to generate favourable news. He encouraged the journalists to think of themselves as part of a "knowledge class", who were undertaking a key role in unifying societies in war (Ericson, Baranek \& Chan, 1987; Frow, 1995). This approach helps to glean a deeper understanding of how Curtin elicited journalists' cooperation to portray his leadership positively in the news media. Thirdly, this article uses a dramaturgy approach to explore the more theatrical aspects of Curtin's techniques to create a media image of him as a trustworthy leader for newsreel audiences. Politics can be staged for the media to create symbolic messages of trust about a leader so as to obtain citizens' support, as Castells $(2007,2008)$ has shown. This study undertakes an innovative examination of Curtin's filmed rehearsals and unissued newsreels, as well as screened appearances (British Movietone News, 1944; Cinesound Productions, 1941; Cinesound review, 1943; Cinesound Review \& Movietone News, 1943; ScreenSound Australia, 1944). An analysis will be made of the camera angles, shots and signs, or meaning, to show how he collaborated with filmmakers to portray the semblance of a close relationship with news audiences.

Fourthly, this article examines the accessibility of Curtin's radio broadcasts to determine his aim to involve journalists in cooperating with him to articulate a personable, likeable image. With this aim, the article uses a readability measurement, the Flesch-Kincaid score. The recommended score for most public documents is about eight, close to the reading level of "middle-brow" newspapers and suitable for an eighth-grade student [59]. Although he cultivated messages as a self-assured speaker, this formula measures his ability to prepare talks that would engage wartime audiences.

\section{Findings and Discussion}

\section{Relations with Journalists}

Involving journalists as a part of governance, Curtin carefully arranged his off-the-record press talks to appear as egalitarian, two-way exchanges of information that persuaded correspondents to support him (Alexander, 1971; Cox, 1973; Ericson, Baranek \& Chan, 1987). He performed rhetorical acts that signified arete, a sense of professional virtue, during his interviews. He pinned his old Australian Journalists' Association badge on his coat to demonstrate his affinity with the reporters (Rodgers, 1971). Although Curtin benefited from censorship, he appeared to lean backwards nonchalantly on his swivel chair at the desk in his blue, upholstered prime minister's office, as if he were "thinking out loud" at his twice-daily interviews (Whitington, 1977, p. 77). His gestures were "couched in the specific language of media" to appear to be a friend to some 10 senior political journalists at the conferences (Castells, 2007, p. 241). Once the prime minister, he encouraged journalists to see themselves as Curtin's travelling "circus", who shared his confidence to an extent previously unknown in Australian press history. Journalists portrayed him as a friend to audiences. As Herald writer, Allan W. Dawes, remarked to readers: "It is easier to be friends with John Curtin, I think, than with almost any other member of the Federal Parliament ... He is a hard reader and an indefatigable worker" (Alexander, 1971; Dawes, 1941; Whitington, 1977). The journalists viewed their roles with more liberation and spontaneity and helped to remove a sense of distance between the prime minister and the people. 
Behind the scenes, Curtin prepared extensively to signify eunoia, or a caring attitude towards journalists. King (June 1, 1944) noted that Curtin "seemed to attach great importance" to his news conference in Ottawa as he "came with material prepared for distribution" and "welcomed questions" from reporters in the Canadian House of Commons. Yet a Time magazine journalist did not notice Curtin's preparations, instead reporting that he delivered an "impromptu account" of Australia's wartime contributions for about an hour ("Canada at war," 1944, p. 16). The journalist reported that he appeared casual and relaxed as "he settled himself into an easy chair" and joked to the correspondents that they could: "Now put on your wig and gown and put me into the witness box". Also, he attempted to establish a friendly atmosphere by saying "the press and parliament are the two great institutions that have a trusteeship in the service of men" (Department of External Affairs, 1944). The Time correspondent added that he "answered directly and enjoyed the session" (Time, 1944, p. 16). While his news interviews appeared as spontaneous, open-ended, and inclusive, he relied on rehearsed rhetoric to generate favourable news.

Curtin also developed a compassionate ethos during his interactions with visiting US journalists. Press secretary, Rodgers, recalled that Curtin was "at great pains to see to their comfort" when American journalists fled to Australia after Singapore's surrender in February 1941(Rodgers, 1971). For example, US journalist Joseph C. Harsch recollected that during his travels, he ordinarily slept on a ship deck with the military personnel and shared army baked beans and unpalatable tea with them. After Harsch arrived in Australia in early 1942, the governorgeneral, Lord Gowrie, invited him to the Government House in Canberra for a weekend that included horseback riding. Harsch reminisced: "The prime minister's office obviously had enlisted the governor general's help in persuading one American reporter to think more kindly of the Australian government"(1993, p. 69). By early 1942, the Australian government was directing the censors on "[t]he need for liberty in handling press messages particularly by U.S.A. correspondents so that Australia may be adequately publicized in that country"(National Archives of Australia, 1942a). Curtin promoted the chief publicity censor's role, which was held by Edmund Garnet Bonney, a former newspaper editor. Bonney issued a memorandum to the states' censors that: "Because of the risk that visiting American journalists may express views inimical to Australia's future, extreme caution is necessary in dealing with articles or statements by them" (Federal Censor, 1942). The preferential treatment included getting "the writer and censor together so that difficulties may be ironed out without a moment's necessary delay" (Bonney to Curthoys, 1942). Through the close, candid talks with Curtin, the correspondents viewed him as an egalitarian colleague and portrayed him to their news audiences as being "friendly," and a "onetime mild-mannered trade union journalist" ("Curtin's Courage Praised," 1942; "Last Bastion," 1942; Talbot, 1942).

Journalists cooperated with Curtin's approach to show him as a likeable, accessible prime minister to the public. US magazine companies used his image in their advertisements including posters in New York subway cars. As a journalist reported, the posters "display an intimate sketch of P.M. Curtin reading in bed with the caption, "Australia's premier reads pulp fiction for exactly one hour in bed every night." US journalists also falsely reported that his favourite reading materials were "magazines of the true-love type" when "everybody must be happy at the end" ("Political roundabout," 1942). Few journalists challenged the prime ministerial wooing of the American press.

\section{Signifying Emotion}

While Curtin confidentially talked with journalists, he expected Australian reporters would cooperate to portray a sense of emotional pride, or eunoia, about the nation. He used dramatic techniques to focus on an imminent crisis. Curtin showed "a great pile" of secret cables to the journalists and confided to them that he had defied Churchill's orders to send some troops to Burma. The journalists agreed to uphold his media embargo during his decision to redirect these troops to Australia. He advised the correspondents that the divisions were making their ocean voyage, without the protection of air cover, to aid national defence. As The Herald's Joseph Alexander (1971) recounted, "although we were staggered at the idea of Curtin opposing the will of a man like Churchill at a time like this, we all felt, I think, proud of him, because he was determined to put Australia first." Through inclusive, dramatic gesturing, confidential briefings and an official news embargo, he secured journalists' cooperation for his campaign on national defence (Commins, 1971; Cox, 1973; Whitington, 1977).

Soon afterwards, Curtin developed informal media interactions to show his genuine concern for the troops' safety, eliciting reporters' support for his risky military strategy. He talked with The Sun bureau chief, Alan Reid, in a train lobby about his nightmares that the troops' ships might be torpedoed. Reid recalled he "tried to comfort" Curtin by playing a card game of bridge in the train, but "periodically you'd see him wipe the sweat from his forehead" (Reid, 1972-1973). One late summer evening in King's Hall, Parliament House, Curtin saw The Sun NewsPictorial's Harold Cox, paused and exclaimed: "Harold! What would you do if you knew their [the troops"] equipment was on another convoy two days behind them?" The next evening, he met Cox by coincidence again. The journalist remarked to Curtin that he looked "a lot better". Curtin replied: "Yes, I feel a lot better, too. They're coming home" (Cox, 1973). Due to his off-the-record talks, he had taken precautions to ensure he would not appear responsible for releasing top-secret messages that benefited him politically. 
Press secretary Don Rodgers promoted the story of Curtin "bringing the troops home" and repeated the anecdote to journalists that the prime minister "couldn't sleep while the boys were still on the water" to ensure the story appeared in the press during the 1943 election campaign. Rodgers (1971) recalled this public relations campaign "was a very smart move" that contributed to the Australian Labor Party achieving its greatest election victory at the time, with Curtin winning 66.9 per cent of the votes for his electoral seat in Fremantle, Western Australia. During the election campaign, Curtin strengthened his role as an accessible prime minister, encouraging journalists to report to the public that they could call him at any time in his electorate of Fremantle, WA. As a newspaper reported: "He was back home in Fremantle and his phone number was in the book if anybody cared to ring him up." The journalist reported that he enjoyed strolling to the local barber, taking his dog for a walk on the beach and "yarned with anybody he met"("The prime minister back home," 1943). During his visits to his home, he promoted the image of an accessible prime minister. As the Sunday Times's Victor Courtney reported:

When he came back he still moved about in the same way, called to see his old friends in the little spare time he had, met and chatted with people in the streets, moved and mixed as he did in the old days ... he was still our friend John(Vee-Cee, 1945, p. 3).

Through this direct communication, Curtin developed appearances of direct relations with journalists and citizens, undermining the wartime conception of "anonymous audiences" (Habermas, 2006, p. 423).

\section{Expanding Media Talks}

Wartime filmmakers also cooperated with Curtin in a variety of newsreels to show him in close-up, eye-level images that portrayed him as an honest, hard-working leader, who often looked directly into the camera to appear on equal terms with his Australian news audiences. The scenes signified his careful cultivation of phronesis or practical wisdom. He rehearsed his words and hand gestures during multiple directors' takes (Cinesound Productions, 1941; Cinesound Review, 1943; ScreenSound Australia, 1944). For example, cinema audiences watched a staged scene, intended to appear as an impromptu media conference, when Curtin spoke his prepared words, "the truth is if we do not strip ourselves to save for our country, the enemy will do it for us with ruthless efficiency, imposing upon us a maximum of misery" (Cinesound Review \& Movietone News, 1943).The filmmakers created the appearance of a factual news report as they showed eye-level images of him, seated at a table, to speak to an assumed group of people, who were not pictured in the scene (ScreenSound Australia, 1944). He might also have benefited from Roosevelt's carefully rehearsed fireside chat newsreels. Moving away from the traditional one-way "push" communications, he transformed prime ministerial news conferences by appearing to initiate more two-way discussions with journalists as a "centerpiece of deliberative politics" involving citizens (Habermas, 2006, p. 423).

Curtin also cultivated friendships with journalists and production crews to help him to project a memorable film image. A reporter recounted that he asked to speak to the 16-year-old sound engineer on a film set: "Straightaway he sat down and drafted his letter to Arthur Brown; a letter that did everything Arthur Brown could wish - recongratulated him, re-affirmed their conversation, re-wished him success in life"(John Curtin Prime Ministerial Library, 1942). Other unedited scenes showed Curtin's enthusiastic exchanges with reporters as he arrived at the Croydon aerodrome for a prime ministers' conference in London. He appeared relaxed, with his hands in his herringbone overcoat pockets, as he interacted with the photographers, film crews and radio and newspaper journalists (British Movietone News, 1944). Curtin befriended filmmaking teams who acted as "cultural workmen" to recreate scenes that showed leaders as the "symbolic embodiment" of trust to news audiences (Castells, 2007, p. 242).

Similarly, Curtin expanded the prime minister's use of radio to develop the semblance of a close relationship between him and listeners. His initiatives included delivering the first speech directly from Australia to US listeners. This study found his radio speeches were generally for a tenth-grade reading level that was appropriate for Australia's average education attainment at the time (1941a, 1942a, 1943a, 1944a). Moreover, Curtin communicated more frequently to radio listeners than did US President Franklin D. Roosevelt, who was recognised for his advanced use of the relatively new media. Curtin made about 12 significant prime ministerial radio addresses each year. In contrast, Roosevelt gave about nine radio talks each year during his presidential terms (Roosevelt \& Rosenman, 1969). News owners kept reporting on Curtin's broadcasts, as well as publishing editorials that encouraged citizen discussions about his statements. While he referred to keywords of freedom and "total liberty", the press was more likely to magnify his rhetoric of a "grave menace" and the enemy(Curtin, 1941a, 1942a, 1943a, 1944a; The Age, The Canberra Times, The Sydney Morning Herald, The West Australian, Dec. 9, 29-30, 1941, Feb. 20, March 16, May 9, Dec. 11, 1942, Feb. 12, 1943, May 9, 1944). As he was increasingly absent from the parliament due to his health problems, The Age editorial writer acknowledged Australian listeners needed to "hear his voice, weigh his words and generally maintain that personal contact with the head of the Government which is eminently desirable"("The steersman returns to the helm," 1944). 
The frequency of his broadcasts, the favourable reception in the selected newspapers, the mass audiences of regular wartime listeners and polls suggested he used radio skilfully to persuade journalists to amplify his compassionate rhetoric ("Curtin and poll," 1943; "Mr. Curtin's job pleases people,", 1942).

\section{Conclusions}

This analysis of Curtin's ethos shows how journalists became a central part of his governance that sustained an overriding perception of his leadership in the news. After Curtin's faltering media relations before his prime ministership, he came to view journalists as crucial in his governance as he used tactics, calculations and technologies to communicate a compassionate image to public audiences. Due to his professional background in news making processes, he developed an exceptionally caring attitude towards journalists. In turn, they portrayed a remarkably accessible and personable prime minister to the public that countered the intense focus on negative stories of foreign threats and enemies. While he and press secretary Rodgers treated journalists as a knowledge class, they carefully structured interviews to appear as unguarded exchanges of information; behind the scenes, they selectively cultivated media messages that would generate favourable news reports about Curtin's spontaneous interactions with citizens. He also appeared to share extensive background information that helped him to convey his compassion towards the nation and Allies. With his knowledge of news routines, he elicited journalists' cooperation to visualize and define an emotional loyalty to the nation. Although the reporters purported to use depictive, realism grammar, their emphases of Curtin's compassionate rhetoric underplayed his tensions with Churchill, controversial military decisions and personal struggles. By magnifying compassionate stories about a caring leadership, Curtin bolstered his stature with journalists.

By the wartime era, the modern media contained the visual, audio and press elements that allowed a leader to communicate personalized messages to mass audiences. Through developing the prime minister's use of dramatic gesturing, inclusive language and close-up, eye-level camera techniques, Curtin attempted to create a sense of a personal connection between him and news audiences. As reporters reproduced his compassionate ethos, the news audiences perceived the war through a selective lens. Filmmakers cooperated to articulate his views to assist with the shaping of public knowledge. With the journalists actively participating in Curtin's governance, they delved beyond observing the world from a distant, detached perspective. The inclusive exchanges between Curtin and journalists serve to show the value of a compassionate style of communicating more personalised messages to the news media during an extended crisis.

\section{References}

Alexander, J. A. (1971). Interview. John Curtin Prime Ministerial Library.

Aristotle. (trans. 2010). Rhetoric. New York: Cosimo Classics.

Aristotle. (trans. 2015). Rhetoric. London: Aeterna Press.

Auer, M. R. (2020). Covid-19 crisis communications: The challenge for environmental organizations. Environmental Science \& Policy. Retrieved from: https://doi.org/10.1016/j.envsci.2020.08.009.

Baldoni, J. (2003). Great communication secrets of great leaders. New York: McGraw-Hill.

Bell, R. L. \& Martin, J. S. (2014). Managerial Communication. New York: Business Expert Press.

Banwart, M. (2020). Communication studies: Effective communication leads to effective leadership. New Directions for Student Leadership. Retrieved from: https://doi.org/10.1002/yd.20371.

Bradenburg, E., \& Braden, W. W. (1958). Franklin Delano Roosevelt. In Marie Kathryn Hochmuth (Ed.), History and Criticism of American Public Address. New York: Longmans, Green and Co.

British Movietone News. (1944). Empire Premiers Assemble. Retrieved from http://www.movietone.com

"Canada at war." (1944, June 12). Time, p. 16,

Carroll, B. (2004). Culture clash: Journalism and the communal atmosphere of the blogosphere, https://conservancy.umn.edu/bitstream/handle/11299/172831/Carroll_Culture\%2 0Clash.pdf? sequence $=1 \&$ is Allowed $=y$

Castells, M. (2007). Communication, power and counter-power in the network society. International Journal of Communication, l(1), 238-266.

Castells, M. (2008). The new public sphere: Global civil society, communication networks, and global governance. The ANNALS of the American Academy of Political and Social Science, 616(1), 78-93.

Churchill, W. S. (1950). The Second World War: The hinge of fate. Boston: Houghton Mifflin Company.

Cicero. (trans. 2016). De oratore. Cambridge: Harvard University Press.

Cinesound Productions. (1941). War in Pacific! [Newsreel]. Bentley: John Curtin Prime Ministerial Library.

Cinesound Review. (1943). This is vital to you! In Compiled speeches of John Curtin [Newsreels]. Bentley: John Curtin Prime Ministerial Library.

Cinesound Review \& Movietone News. (1943). Two years ... Dec. 7 1941-1943. In John Joseph Curtin 1885-1945 [Newsreels].John Curtin Prime Ministerial Library. 
Coatney, C. (2016). John Curtin: How He Won Over the Media. North Melbourne: Australian Scholarly Publishing.

Commins, J. (1971). Interview. John Curtin Prime Ministerial Library.

Cox, H. (1973). Interview by Mel Pratt. John Curtin Prime Ministerial Library.

Craig, G. (2016). Performing politics: Media interviews, debates and press conferences. Cambridge: Polity Press.

Curtin, J. (1917). Our bookshelf. John Curtin Prime Ministerial Library.

Curtin, J. (1936). Letter to young John. John Curtin Prime Ministerial Library.

Curtin, J. (1941a). Announcement that Australia is at war with Japan. John Curtin Prime Ministerial Library.

Curtin, J. (1941b, December 27). The task ahead. The Herald, p. 1.

Curtin, J. (1942a). John Curtin's speech to America. John Curtin Prime Ministerial Library.

Curtin, J. (1942b). Naval Engagement - Coral Sea. Digest of Decisions and Announcements and Important Speeches by the Prime Minister (Right Hon. John Curtin), 28, 4-5.

Curtin, J. (1942c). Attack on Darwin. Digest of decisions and announcementsand important speeches by the prime minister (Right Hon. John Curtin), 19, 8-9.

Curtin, J. (1942d). State of the war. Digest of decisions and announcements and important speeches by the prime minister (Right Hon. John Curtin), 47, 17-24.

Curtin, J. (1943a). General election ALP policy statement. John Curtin Prime Ministerial Library.

Curtin, J. (1943b, February 11). Commonwealth of Australia: Parliamentary Debates, 173, 592-596.

Curtin, J. (1943c, December 14). State of the war. John Curtin Prime Ministerial Library.

Curtin, J. (1944a). Broadcast by the prime minister from London. John Curtin Prime Ministerial Library.

Curtin, J. (1944b, July 17). Meeting of prime ministers - Australian prime minister's report. John Curtin Prime Ministerial Library.

Curtin and poll. (1943, August 23). Time, p. 34.

"Curtin's Courage Praised." (1942, January 12). The New York Times. Retrieved from www.nytimes.com

Davis, A. (2019). Political communication: A new introduction for crisis times. Cambridge: Polity Press.

Dawes, A. (1941, October 6). Men you should know about. John Curtin Prime Ministerial Library.

Day, D. (2006). John Curtin: A life. Pymble: HarperCollins.

Day, T. (2008). Twelve writing tips for administrative staff. University of Bath.

Department of External Affairs. (1944). Visit of Mr. Curtin to USA \& UK in connection with Prime Ministers' Conference London. Bentley: John Curtin Prime Ministerial Library.

Dix, A. (2015). Ethos in Sports: An Aristotelian examination focused on source credibility and the modern day athlete. Sport Science Review, 24(5-6), 267-284.

DuBrin, A. J. (Ed.), Handbook of research on crisis leadership in organizations (pp. 3-22). Cheltenham: Edward Elgar Publishing Inc.

Dworznik-Hoak, G. (2020). Emotional labor during disaster coverage: Exploring expectations for emotional display. Journalism Practice. doi: 10.1080/17512786.2020.1816858.

Ericson, R. V., Baranek, P. M. \& Chan, J. B. L. (1987). Visualizing deviance: A study of news organizations. Milton Keynes: Open University Press.

Faessel, V., Falk, R. \& Curtin, M. (2020). On public imagination: A political and ethical imperative. New York: Routledge.

Federal Censor. (1942, February 17). Telegram. Canberra: National Archives of Australia.

Fife, B. L. (2018). Winning the war on poverty: Applying the lessons of history to the present. Santa Barbara: Praeger.

Fisher Liu, B., Iles, I. A. \& Herovic, E. (2020). Leadership under fire: How governments manage crisis communication. Communication Studies, 71(1), 128-147.

Habermas, J. (1989). The structural transformation of the public sphere: An inquiry into a category of bourgeois society. Cambridge: MIT Press.

Habermas, J. (2006). Political communication in media society: Does democracy still enjoy an epistemic dimension? The impact of normative theory on empirical research. Communication Theory, 16(4), 411426.

Hallahan, K. (2003). W.L. Mackenzie King:Rockefeller's "other" public relations counsellor in Colorado. Public Relations Review, 29(4), 401-414.

Hannides, T. (2015). Humanitarian broadcasting in emergencies - A synthesis of evaluation findings. Research Report Issue 7. London: BBC Media Action.

Harsch, J. C. (1993). At the Hinge of History: A Reporter's Story. Athens: The University of Georgia Press Athens.

Holcomb, C. (2001). "The crown of all our study:" Improvisation in Quintilian's Institutio Oratoria. Rhetoric Society Quarterly, 31(3), 53-72. 
Jackson, A. (2007). "Churchill: warrior and writer", The Round Table: The Commonwealth Journal of International Affairs, 96(2), 193-199.

John Curtin Prime Ministerial Library. Note dated Friday 13th from Elsie Macleod to Tom Fitzgerald. Bentley: John Curtin Prime Ministerial Library, 1942.

King, W. L. M. (1893-1950). The diaries of William Lyon Mackenzie King. Ottawa: Library and Archives Canada.

"Last Bastion." (1942, March 23). Time, p. 27.

Len-Rios, M. E., Hinnant, A. \& Park, S-A. (2009). Health news agenda building: Journalists' perceptions of the role of public relations, Journalism \& Mass Communication Quarterly, 86(2), 315-331.

Lim, E. T. (2003). The lion and the lamb: De-mythologising Franklin Roosevelt's fireside chats. Rhetoric \& Public Affairs, 6(3), 437-64.

Lloyd, C. J. (1988). Parliament and the press: The federal parliamentary press gallery 190188. Carlton: Melbourne University Press.

Lloyd, C., \& Hall, R. (Eds.). (1997). Backroom briefings: John Curtin's war. Canberra: National Library of Australia.

López, C. R. (2013). The common (mediocris) orator of the late republic: the Scribonii Curiones. In C. Steel \& H. van der Blom (Eds.), Community and communication: Oratory and politics in republican Rome (pp. 287-299). Oxford: Oxford University Press.

Marsh, C. (2006). Aristotelian ethos and the new orality: Implications for media literacy and media ethics. Journal of Mass Media Ethics, 21(4), 338-352.

Moss, J. (1997). Reclaiming Aristotle's "Rhetoric". The Review of Metaphysics, 50(3), 635-646.

"Mr. Curtin's job pleases people," The Courier-Mail, Aug. 14, 1942. Bentley: John Curtin Prime Ministerial Library.

Murphy, J. J. (1974). Rhetoric in the Middle Ages: A history of rhetorical theory from Saint Augustine to the Renaissance. Berkeley: University of California Press.

National Archives of Australia. (1942a, January 10). W.P. Ashley to F.M Forde. Canberra: National Archives of Australia.

National Archives of Australia. (1942b, February 20). Bonney to R.L. Curthoys. Canberra: National Archives of Australia.

Nicotera, A. M. (Ed.) (2020). Origins and traditions of organizational communication: A comprehensive introduction to the field. New York: Routledge.

Perloff, R. M. (1998). Political communication: Politics, press, and public in America. New Jersey: Lawrence Erlbaum Associates.

Peters, J. D. (1996). The uncanniness of mass communication in interwar social thought. Journal of Communication 46(3), 108-23.

"Political roundabout." (1942, October 11). The Daily Telegraph, p. 11.

Public Broadcasting Service. (2009). The Online NewsHour, http://www.pbs.org/newshour/bb/media/jan-june09/obama_06-24.html

Quintilian. (trans. 1891). Institutes of Oratory. Stanford University Libraries, https://archive.org/details/quintiliansinst05quingoog

Ratzan, S. C., Sommariva S. \& Rauh, L. (2020). Enhancing global health communication during a crisis: lessons from the COVID-19 pandemic. Public Health Research \& Practice, 30(2). Retrieved from: https://doi.org/10.17061/phrp3022010

Raupp, J. (2019). Crisis communication in the rhetorical arena. Public Relations Review, 45(3). Retrieved from: https://doi.org/10.1016/j.pubrev.2019.04.002

Raymond, J. (2005). The invention of the newspaper: English news books 1641-1649. Oxford: Clarendon Press.

Reid, A. D. (1972-1973). Interview by Mel Pratt [Interview transcript]. Bentley: John Curtin

Prime Ministerial Library.

Rodgers, D. K. (1971). Interview. John Curtin Prime Ministerial Library.

Roosevelt, F. D. \& Rosenman, S. I. (1969). The Public Papers and Addresses of Franklin D. Roosevelt. New York: Russell and Russell, 13 vols.

ScreenSound Australia. (1944). Parliament in session [Newsreel]. Bentley: John Curtin Prime Ministerial Library.

Smith, C. R. (2004). Ethos dwells persuasively: A hermeneutic reading of Aristotle on credibility. In M. J. Hyde (Ed.), The ethos of rhetoric (pp. 1-19). Columbia: University of South Carolina Press.

Tait, S. (2008, March 8). A war leader's love affair with the press. The Times, p. 80.

Talbot, G. (1942, January 11). “Australian Prime Minister Blunt, Friendly,” The Washington Post. Retrieved from washingtonpost.com

“The prime minister back home," Sunday Telegraph. Bentley: John Curtin Prime Ministerial Library, May 2, 1943. 
The steersman returns to the helm (1945, January 22). John Curtin Prime Ministerial Library.

Thomson, T. J. (2018). Mapping the emotional labor and work of visual journalism. Journalism, doi: $10.1177 / 1464884918799227$.

Vee-Cee, "Our friend, John Curtin," Sunday Times, p. 3, July 8, 1945.

Wahl-Jorgensen, K. (2020). An emotional turn in journalism studies? Digital Journalism, 8(2), 175-194.

Waters, R. D., Tindall N. T. J. \& Morton, T. S. (2010). Media catching and the journalist-public relations practitioner relationship: How social media are changing the practice of media relations, Journal of Public Relations Research, 22(3), 241-264.

Whitington, D. (1977). Strive to be fair. Canberra: Australian National University Press.

Young, P. (1999). The context. In S. Harrison (Ed.,) Disasters and the media: Managing crisis communications (pp. 7-16). New York: Palgrave Macmillan. 